\title{
A Comparative Study on the Factors that Affect Exports of Chinese Agricultural Products to Japan and South Korea
}

\author{
Zhuiqiao $\mathrm{JIN}^{\mathbf{1}}$, Fengmin YANG ${ }^{2}$ \\ ${ }^{1}$ School of Business East China University of Science and Technology, No. 130, Meilong Road, Shanghai, China \\ ${ }^{2}$ School of Business East China University of Science and Technology, No. 130, Meilong Road, Shanghai, China \\ jinzhuiqiao@163.com,yfengmin@ecust.edu.cn
}

\begin{abstract}
This paper applies the CMS model to analyze the influencing factors of Chinese agricultural products exported to Japan and South Korea. Our empirical study shows that growth factor is the leading factor that facilitates Chinese agricultural exports. Specifically, product structure effect promotes Chinese exports to Japan; product competitive effect promotes Chinese exports to Korea; while the low comprehensive competitiveness is the main barrier to the exports of Chinese agricultural products. These research results suggest that paying high attention to food security, establishing technical exchange platform of agricultural products and promoting the standardization of quarantine are important for increasing China's exports of agricultural products.
\end{abstract}

Index Terms - agricultural products; exports; CMS model

\section{Introduction}

From 2001 to 2012, Chinese agricultural export scale to Japan and Korea has constantly expanded. However, the product structure has undergone very little change. In order to clearly analyze the influencing factors of Chinese agricultural exports to Japan and Korea, furthermore, to figure out the causes of promotive and obstructive factors of Chinese agricultural exports, this paper applies CMS Model and analyzes sequential variation of the influencing factors of Chinese agricultural exports to Japan and Korea and trend variation of five factors. Based on these results, this paper proposes the similarities and differences of Chinese agricultural exports to Japan and Korea. Thereby, suggestions can be properly presented.

\section{Construction of the Model}

Constant Market Share Model (CMS Model) is commonly used to analyze the export market. The factors affecting a country's trade are often separated into market factors (global market demand), commodity composition and commodity competitive power. This essay will put an emphasis on studying the influencing factors of China's agricultural products exported to Japan and South Korea, and at the same time focus on the analysis of the competitive power of Chinese agricultural products. Therefore CMS Model is adopted as follows.

$$
\Delta q=\sum_{i} S_{i}^{\mathrm{o}} \Delta Q_{i}+\sum_{i} \Delta S_{i} Q_{i}^{\mathrm{o}}+\sum_{i} \Delta S_{i} \Delta Q_{i}
$$

(Structure Effect) (Competitive Effect) (Cross Effect)

$$
\begin{aligned}
& \Delta \mathrm{q}= \\
& \mathrm{S}^{\circ} \Delta \mathrm{Q}+\left\lceil\sum_{\mathrm{i}} \mathrm{S}_{\mathrm{i}}^{\circ} \Delta \mathrm{Q}_{\mathrm{i}}-\mathrm{S}^{\circ}\right. \\
& \Delta \mathrm{SQ}^{\circ} 1+\sum_{\mathrm{i}} \Delta \mathrm{S}_{\mathrm{i}} \Delta \mathrm{Q}_{\mathrm{i}}
\end{aligned}
$$

(Growth Effect) (Product Structure Effect) (Comprehensive Competitive Effect) (Product Competitive Effect) (Cross Effect)

"Structure Effect" as mentioned above means the changes in the product exports of a country caused by the changes of the importing scale and structure of products in this country; "Competitive Effect" refers to the changes of a product export due to the change of the product exports competitive power of this country. "Structure Effect", at the second level, can be separated into "Growth Effect" and "Product Structure Effect"; "Competitive Effect", into "Comprehensive Competitive Effect" and "Product Competitive Effect". "Growth Effect" can be defined as the growth of one agricultural product export of the exporting country because of the general growth of the importing country's imports. "Product Structure Effect" is applied to see if the exports of one country are focused on the importing products of the importing country which grow more rapidly. "Comprehensive Competitive Effect" means the growth of exports brought about by changes of the overall competitiveness of agricultural products; "Product Competitive Effect" is the contribution of the growth of certain agricultural products exports to the total exports growth. "Cross Effect" is used to measure matching degrees between the exporting products of one country and the enlarged imports of the target market.

\section{Data Resources and Analysis}

For the sake of better carrying out the model analysis, the agricultural products are sorted into four types: Live Animals:

\footnotetext{
${ }^{*}{ }^{1} \Delta \mathrm{q}$ respectively represents changes of the total amount of export of Chinese agricultural products to Japan and South Korea; Q respectively represents the total amount of agricultural products import of Japan and South Korea; $Q^{\mathrm{i}}$ represents the total amount of agricultural producti import of Japan or South Korea; $\mathrm{S}$ represents the ratio of total amount of Chinese agricultural products export among the agricultural products import of Japan or South Korea; $\mathrm{S}^{\mathrm{i}}$ means the ratio of total amount of Chinese agricultural product $i$ export among the agricultural product $\mathrm{i}$ import of Japan or South Korea; O refers to base period.
} 
animal products (HS:01-05); Plant Products (HS: 06-14); Animal and Vegetable Fats and Oils and their Analytical Products, Refined Edible Oils And Fats, Animal and Plant Wax(HS: 15); Food, Drink, Wine and Vinegar, Tobacco and Tobacco Substitute (HS: 16-24), based on Commodity Classification for China Customs Statistics.

As the change of macro-environment in China, Japan and South Korea is not integrated into the analysis formulae as one variable by the model, the writer has adopted the data from 1997 to 2012 and got the decomposition results of the export growth from 1998 to 2012, in terms of the international environment changes at that time. Moreover, it is divided into three different phases, "1998-2001", "2002-2007", and "20082012". The main reason why it is divided into three phases is that the financial crisis hit Asia in 1997, and China's agricultural products export appeared to have a liberalization tendency in 1998; since 2001, China has successfully entered into the WTO; the global financial crisis in 2008 began to affect the agricultural products import of Japan and South Korea by different level.

\section{A. Influencing Factors on Exports of Chinese Agricultural Products to Japan}

According to CMS Model calculation results, it is evident that the five influencing factors on the export of Chinese agricultural products to Japan have all changed, but they still show a considerably obvious trend.

1) Time series analysis at the first level of decomposition

As shown in table 1, at the first level of decomposition, the export growth of Chinese agricultural products to Japan results from interactions of Structure Effect, Competitive Effect and Cross Effect.

In the first phase (1998-2001), the export of Chinese agricultural products to Japan increased by $\$ 376$ million. The competitive effect was the dominant factor whose contribution rate was $188.25 \%$, while the contribution rate of structure effect was $-75.73 \%$. Therefore, from 1998 to 2001, the export growth of Chinese agricultural products to Japan mainly profited from the competitive enhancement of the agricultural products themselves while the import demand of Japan for agricultural products and the change of its product import structure hindered the export of agricultural products in China.

In the second phase (2002-2007), the strong competitiveness of Chinese agricultural products is the main factor in stimulating the export growth of Chinese agricultural products to Japan, the contribution rate of which reached $57.47 \%$, leading to an increase in the export of agricultural products of $\$ 2.169$ billion. In the meantime, the rate of structure effect and cross effect reached $29.71 \%$ and $12.82 \%$ respectively, jointly driving the export growth. It is also suggested that in this phase, that the export of Chinese agricultural products to Japan fitted in well with the change of Japanese agricultural import demand, and was well suited to the structural changes in Japanese agricultural products import.

In the third phase (2008-2012), competitive effect was no longer the dominant factor and the declining competitiveness posed negative effects, making exports decrease by $\$ 578$ million; besides, the export of Chinese agricultural products to Japan cannot be well suited to Japan's agricultural market changes. As a consequence, the negative effects of cross effect impeded the export of Chinese agricultural products to Japan. Only the structure effect promoted the export of Chinese agricultural products to Japan, whose contribution rate reached $153.44 \%$, making the export of Chinese agricultural products to Japan increase by $\$ 2.415$ billion and making up the loss caused by the negative effect brought by competitive effect and cross effect.

TABLE 1 Decomposition Results about the Influencing Factors on Export Trade of Chinese Agricultural Products to Japan

Unit: Billion USD, \%

\begin{tabular}{|c|c|c|c|c|c|c|}
\hline & \multicolumn{2}{|c|}{ The first phase 1998-2001 } & \multicolumn{2}{|c|}{ The second phase 2002-2007 } & \multicolumn{2}{|c|}{ The third phase 2008-2012 } \\
\hline Growth factors & absolute volume & percentage & absolute volume & percentage & absolute volume & percentage \\
\hline Real export growth & 3.76 & 100 & 21.69 & 100 & 15.74 & 100 \\
\hline \multicolumn{7}{|c|}{ The first level of decomposition } \\
\hline Structure Effect & -2.85 & -75.73 & 6.44 & 29.71 & 24.15 & 153.44 \\
\hline Competitive Effect & 7.09 & 188.25 & 12.46 & 57.47 & -5.78 & -36.70 \\
\hline Cross Effect & -0.47 & -12.53 & 2.78 & 12.82 & -2.63 & -16.74 \\
\hline \multicolumn{7}{|c|}{ The second level of decomposition } \\
\hline Growth Effect & -3.08 & -81.87 & 4.84 & 22.33 & 22.03 & 139.97 \\
\hline Product Structure Effect & 0.23 & 6.15 & 1.60 & 7.38 & 2.12 & 13.47 \\
\hline Comprehensive Competitive Effect & 7.33 & 194.83 & 15.36 & 70.83 & -4.81 & -30.59 \\
\hline Product Competitive Effect & -0.25 & -6.57 & -2.90 & -13.36 & -0.96 & -6.11 \\
\hline Cross Effect & -0.47 & -12.53 & 2.78 & 12.82 & -2.63 & -16.74 \\
\hline
\end{tabular}

Data source: computed in terms of the data from 1997to 2012 from UNSD (http://comtrade.un.org/db) 
2) Analysis of influencing factors changes at the second level of decomposition

At the second level of decomposition, structure effect is decomposed into growth effect and product structure effect; competitive effect, into comprehensive competitive effect and product competitive effect.

Growth effect produced negative effect until 2001, not promoting the export of Chinese agricultural products to Japan. Since 2002, it had been the dominant factor in fuelling the export of Chinese agricultural products to Japan. This is also consistent with the changes of the ratio of the total amount of Chinese agricultural products export among the global agricultural products import of Japan. In 2002, Chinese agricultural products export accounted for $12.2 \%$ of the total amount of the target market import, and gradually rose to $14.9 \%$. However, it began to decline in 2007.

Product structure effect produced positive effects in all three phases. Therefore, it demonstrates that the exports of Chinese agricultural products to Japan focused on the faster growing imported products of Japan; China is the main importer of Japanese agricultural products, and the structure of

As is shown in the data changes related to comprehensive competitive effect, the whole competitiveness of China's exported agricultural products to Japan was the principal factor to promote the export of Chinese agricultural products to Japan; however, in the third phase comprehensive competitive effect showed negative, which hindered the export of Chinese agricultural products to Japan.

Product competitive effect produced the negative effect in all the three phases, which means China's special agricultural competitiveness was low. In the second phase, product competitive effect even declined, the reason for which is thought to be related to Positive List System made by Japan in 2006. The data in the third phase, however, reveal that the export of Chinese agricultural products was correspondingly adjusted in response to the adverse impact produced by the Positive List System.

The changes of cross effect show, except for the higher match degree between the export structure of China's agricultural products and the larger amount of imported agricultural products of Japan in the second phase, in the other two phases the degree went in the other direction.

\section{B. Influencing Factors on Exports of Chinese Agricultural Products to South Korea}

According to CMS Model calculation results, it is evident to see that the five influencing factors on the export of Chinese agricultural products to South Korea have all changed, but they still show a considerably obvious trend.

1) Time series analysis at the first level of decomposition

As shown in table 2, at the first level of decomposition, the export growth of Chinese agricultural products to South Korea results from interactions of Structure Effect, Competitive Effect and Cross Effect.

In the first phase (1998-2001), the export of Chinese agricultural products to South Korea decreased by $\$ 36$ million. The competitive effect was the dominant factor to stimulate the export to South Korea whose contribution rate was392.33\%; however, structure effect and cross effect functioned together in hindering the export of Chinese agricultural products to South Korea, especially the structure effect, which means the domestic agricultural products import demand in South Korea and the structure of the import demand hindered the export of Chinese agricultural products to South Korea, having made the export decrease by $\$ 170$ million. Therefore, from 1998 to 2001, the export growth of Chinese agricultural products to South Korea mainly benefited from China's agricultural products' competitiveness.

In the second phase (2002-2007), structure effect became the dominant factor in stimulating exports to South Korea, whose contribution rate was $54.61 \%$, boosting the agricultural exports to $\$ 773$ million. Additionally, the contribution rate of structure effect, competitive effect and cross effect reached $28.69 \%$ and $16.69 \%$ respectively, jointly driving the export growth. It also suggested in this phase (2002-2007), that the domestic agricultural products import demand in South Korea grew rapidly, and the export of Chinese agricultural products to South Korea was well suited to the changes of the South Korea's import demand.

In the third phase (2008-2012), competitive effect declined, producing the negative effect, which made the export decrease by $\$ 607$ million; in addition, the export of Chinese agricultural products to South Korea could not fit well into the changes of the South Korea's agricultural products market. Therefore, the negative effect produced by the cross effect hindered the export of Chinese agricultural products to South Korea. Only the structure effect promoted the export of Chinese agricultural products to South Korea, whose contribution rate was $248.67 \%$, and making the export to South Korea increase by $\$ 1.804$ billion, and made up for the loss caused by the negative effect brought by competitive effect and cross effect. 
TABLE 2 Decomposition results about the factors of the export trade growth of Chinese agricultural products to South Korea

Unit: Billion USD, \%

\begin{tabular}{|c|c|c|c|c|c|c|}
\hline & \multicolumn{2}{|c|}{ The first phase $1998-2001$} & \multicolumn{2}{|c|}{ The second phase $2002-2007$} & \multicolumn{2}{|c|}{ The third phase $2008-2012$} \\
\hline Growth factors & absolute volume & percent-age & absolute volume & percent-age & absolute volume & percent-age \\
\hline Real export growth & -0.36 & 100 & 14.15 & 100 & 7.25 & 100 \\
\hline \multicolumn{7}{|c|}{ The first level of decomposition } \\
\hline Structure Effect & -1.70 & 466.19 & 7.73 & 54.61 & 18.04 & 248.67 \\
\hline Competitive Effect & 1.43 & -392.33 & 4.06 & 28.69 & -6.07 & -83.75 \\
\hline Cross Effect & -0.10 & 26.14 & 2.36 & 16.69 & -4.71 & -64.92 \\
\hline \multicolumn{7}{|c|}{ The second level of decomposition } \\
\hline Growth Effect & -1.76 & 483.81 & 7.91 & 55.92 & 18.10 & 249.59 \\
\hline Product Structure Effect & 0.06 & -17.62 & -0.18 & -1.31 & -0.07 & -0.92 \\
\hline Comprehensive Competitive Effect & 1.63 & -447.20 & 3.77 & 26.62 & -6.42 & -88.48 \\
\hline Product Competitive Effect & -0.20 & 54.87 & 0.29 & 2.07 & 0.34 & 4.73 \\
\hline Cross Effect & -0.10 & 26.14 & 2.36 & 16.69 & -4.71 & -64.92 \\
\hline
\end{tabular}

Data source: computed in terms of the data from 1997to 2012 from UNSD (http://comtrade.un.org/db)

2) Analysis of influencing factors changes at the second level of decomposition

At the second level of decomposition, structure effect is decomposed in the same way, into growth effect and product structure effect; competitive effect, into comprehensive competitive effect and product competitive effect.

Grow effect is always the main factor to affect the export trade of Chinese agricultural products to South Korea, whose contribution rate is far higher than other influencing factors. The changes of the export of Chinese agricultural products to South Korea chiefly result from the rapid growth of the domestic agricultural products import demand in South Korea, which is consistent with the share changes of the exports of Chinese agricultural products to South Korea and the total amount of South Korea's agricultural products import. During the years from 2002 to 2007, the share of the export of Chinese agricultural products to South Korea and the total amount of South Korea's agricultural products import was fairly high, once as high as $23 \%$. However, in the first phase and the third phase, the share reduced by $15 \%$. In other words, the growing export of Chinese agricultural products to South Korea did not increase the market share of agricultural products in South Korea imported from China.

Structure effect was negative all the time in the different phases; that is to say, China's agricultural products export failed to concentrate on several more fast-growing imported agricultural products in the domestic market of South Korea; and China's agricultural products export was not quickly suited to structural changes of South Korea's demand for the imported products.

The changing amplitude of comprehensive competitive effect was fairly larger, and improved in the second phase, whose contribution rate reached up to $26.62 \%$, but in the third phase it dropped to $-88.48 \%$. According to the study on the South Korea's regulations of agricultural products inspection and quarantine, the changing amplitude is much related to the standards and specifications of relevant food, food additives, livestock product process, revised frequently by South Korea after 2008.

Product competitive effect indicates that some of the exported products to South Korea possess relatively stable competitiveness. The reason is that the index of product competitive effect produced positive effect in the three different phases.

Cross effect was consistent with the structure of South Korea's market demand for agricultural products in the first phase and the second phase. In the third phase, the contribution rate of cross effect was negative, which indicates China's exported agricultural products to South Korea do not belong to the larger scale of the South Korea's imported products. In other words, the structure of South Korea's agricultural

\section{Comparative Study on Influencing Factors on Exports of Chinese Agricultural Products to Japan and Korea}

\section{A. South Korea'S Domestic Market Demand for Chinese Agricultural Products is Larger than Japan 'S}

In the related analysis of the three phases, it can be clearly seen that the contribution rate of "growth effect" in South Korea was much higher than the other factors, and even reached higher than $200 \%$ in the first phase and the third phase. This also means that South Korea's domestic demand for agricultural products is the dominant factor to affect Chinese agricultural products export. However, the contribution rate of "growth effect" in Japan was 139\%only in the third phase, and not high in the other two phases. The ratio of growth effect (in South Korea) was 483.81\%, 590 times higher than that (in Japan). In the second phase, although the contribution rate of growth effect sharply dropped to $55.92 \%$, yet higher than that (in Japan). In the third phase, the contribution rate of growth effect (in South Korea) was nearly twice as higher as that (in Japan). The above proves that the influence of the growth of the demand for agricultural products on the growth of China's agricultural products export 
to Japan is greater than its influence on the growth of China's export to South Korea.

\section{B. The Comprehensive Competitive of Chinese Agricultural Products in Japan'S Market is Higher than That in South Korea 'S Market}

In conclusion, the comprehensive competitiveness of Chinese agricultural products is not high. Especially in 2008, Japan and South Korea frequently reinforced the criteria of technical barriers to trade, which enlarged the coverage area of agricultural products inspection so that the comprehensive competitive of Chinese agricultural products declined obviously. But from the perspective of nationality, the comprehensive competitiveness of Chinese agricultural products in Japan has always had more obvious price advantages; although it produced negative effects in the third phase, the effect of the negative contribution rate was 30.59\%. However, in South Korea, the comprehensive competitiveness of Chinese agricultural products was negative all through the three phases, hindering the export of Chinese agricultural products to South Korea. In the third phase, its contribution rate was $-88.48 \%$, higher than that in Japan. Therefore it is observed that the comprehensive competitive of Chinese agricultural products in Japanese market was slightly higher than that in Korean market.

\section{C. the Structure of Chinese Agricultural Products Export to Japan is Superior to That to South Korea}

Though various factors fluctuated much, yet the factor of product structure brought forth comparatively obvious changes. From 1998 to 2012, of the influencing factors on the export of Chinese agricultural products to Japan, product structure was positive all the time; but to South Korea, the product structure was negative all the way. In other words, the structure of Chinese agriculture products export to Japan is relatively good, which is consistent with the current situation: China's corresponding exported products are mainly aquatic products and vegetables while the variety of Chinese agriculture products export to South Korea always changes and the structure is not stable.

\section{Chinese Agricultural Products in South Korea Shows A Stronger Competitive Advantage}

The structure of Chinese agriculture products exports to South Korea is less than satisfactory, but as the product competitive effect shows, it promoted the export growth of Chinese agricultural products to South Korea all through the phases from 1998 to 2012, which means some of China's exported agricultural products to South Korea have comparatively obvious competitive advantage.

\section{Policy Suggestion}

\section{A. Pay High Attention to Food Security and Improve the Quality of Agricultural Products Imported into Japan and Korea}

China's export structure of agricultural products in Japan and Korea has reached a lower level. The agricultural products imported to the two countries are mainly primary ones, which would influence the competitiveness of Chinese agricultural products in the markets of Japan and Korea. Therefore, from the perspective of food security, the quality of production, processing and transportation of agricultural products should be guaranteed by scientific and reasonable ways of production and logistics when these products enter into Japan and Korea. Meanwhile, the related government departments should also strengthen supervision.

\section{B. Establish Technical Exchange Platform of Agricultural Products and Improve the Quality of Chinese Agricultural Products}

In order to further boost the trade liberalization among the three countries and reduce trade tensions, it is necessary to establish the technical exchange platform of agricultural products. While China's technology of agricultural products achieves development, Japan, Korea and China are supposed to research on the common problems among the three countries and promote common improvements in agriculture.

\section{Promote the Standardization of Quarantine at The Same Pace among Japan, Korea and China}

Japan, Korea and China should promote the standardization of quarantine at the same pace. Because of the low quality of China's agricultural products, Japan and Korea respectively set tedious processes of quarantine. Worse still, Korea doesn't recognize the test and certification of China. If trade liberalization is to be realized, the tedious process of quarantine then not only leads to trade tensions, but also wastes big capitals. Hence, it's necessary for the three countries to standardize the process of quarantine and allow for the difference among countries within a certain framework.

\section{References}

[1] H. Tyszynski, "World Trade in Manufactured Commodities," The Manchester School, vol. 19, no. 3, pp. 272-304, 1951.

[2] J. D. Richardson, "Some sensitivity tests for a Iconstant-market-shares analysis of export growth", The Review of Economics and Statistics, vol. 53, no. 3, pp. 300-304, 1971.

[3] J. Fagerberg, and G. Sollie, "The method of constant market shares analysis reconsidered," Applied Economics,vol.19,no.12,pp. 1571-1583, 1988.

[4] C. Milana, "Constant-market-shares analysis and index number theory," European Journal of Political Economy, vol. 4, no. 4, pp. 453-478, 1988.

[5] SH, Oh, and NC. Whitley, "Pork Production in China, Japan and South Korea," Asian-Australasian journal of animal sciences, vol. 24, pp. 1629-1636, 2011.

[6] Lijun. Cao, and Zhuang. Zhou, "An Analysis on Competition and Cooperation of the Textile Clothing Industry after the Establishment of China, Japan, South Korea FTA," Advanced Materials Research, pp. 332-334, 2011.

[7] Innwon. Park, "Regional Trade Agreements in East Asia: Will They Be Sustainable," Asian Economic Journal, vol. 23, pp. 169-194, 2009. 